\title{
Hemato-biochemical changes during xylazine-ketamine and xylazine-thiopentone anesthesia in
} dogs

\author{
M. R. Munif ${ }^{1,2}$, M. M. Alam ${ }^{1}$, M. R. Alam, ${ }^{1, *}$
}

${ }^{1}$ Department of Surgery and Obstetrics, Faculty of Veterinary Science, Bangladesh Agricultural University, Mymensingh-2202, Bangladesh (MM Alam: mahmud.dso@bau.edu.bd; MR Alam: alammr@bau.edu.bd)

${ }^{2}$ Veterinary Teaching Hospital, Bangladesh Agricultural University, Mymensingh-2202, Bangladesh (MR Munif: md.raguibmunif@gmail.com)

\begin{abstract}
Background: This study was conducted to evaluate certain hemato-biochemical changes during Xylazine-Ketamine (X-K) and Xylazine-Thiopentone (X-T) anesthesia in dogs.

Methods: For this, six dogs of 18 to $25 \mathrm{~kg} \mathrm{BW}$ were selected and divided into two groups: Group I (X-K) and Group II (X-T). Atropine sulfate @ $0.05 \mathrm{mg} / \mathrm{kg} \mathrm{BW} \mathrm{(IM)} \mathrm{was} \mathrm{used} \mathrm{for} \mathrm{premedication}$ in both groups. Dogs in Group I (n=3) were anesthetized with Xylazine $\mathrm{HCl} @ 1.1 \mathrm{mg} / \mathrm{kg} \mathrm{BW}$ (IM) and Ketamine HCl @ 5.5 mg/kg BW (IM), whereas Xylazine $\mathrm{HCl} @ 1.1 \mathrm{mg} / \mathrm{kg} \mathrm{BW}$ (IM) and Thiopentone sodium @ $20 \mathrm{mg} / \mathrm{kg} \mathrm{BW}$ (IV) were used for anesthesia in Group II ( $\mathrm{n}=3)$. In both groups, peripheral blood samples were collected from the dogs before induction of anesthetic agents (control) and thereafter on 10,20,30, and 40 minutes of post-induction and again after complete recovery from anesthesia to evaluate hematological changes in Total Erythrocyte Count (TEC), Hemoglobin ( $\mathrm{Hb}$ ) and Packed Cell Volume (PCV). In addition, serum biochemical changes in Total Serum Protein (TSP), Blood Urea Nitrogen (BUN), Creatinine, Sodium (Na), Potassium $(\mathrm{K})$, and Chloride $(\mathrm{Cl})$ were also assessed in both groups.

Results: TEC, Hb, and PCV were altered significantly $(\mathrm{P}<0.05)$ in most of the cases, TSP was decreased significantly $(\mathrm{P}<0.05)$ but $\mathrm{BUN}$ was increased significantly $(\mathrm{P}<0.05)$, and creatinine was also increased in both groups during the experiment. There were mild alterations in $\mathrm{Na}, \mathrm{K}$, and $\mathrm{Cl}$ values after induction, and found near to the baseline (control) after recovery.

Conclusions: These findings ascertained that the anesthetic combinations of $\mathrm{X}-\mathrm{K}$ and $\mathrm{X}-\mathrm{T}$ assert some definite hemato-biochemical changes in dogs which should be carefully judged by the veterinarians during surgical interventions to avoid anesthesia-related risks and complications. Keywords: TEC, Hb, PCV, TSP, BUN, Creatinine, Electrolytes
\end{abstract}




\section{Munif and others}

\section{Introduction}

Various combinations of anesthetic agents are often used for general anesthesia in dogs (Anandmay et al., 2016) during major and minor surgical approaches (Cima et al., 2016) for fracture, tumor, spaying, castration, gastrotomy, cystotomy, enterectomy (Munif et al., 2020) and so on. Brodbelt (2006) reported that anesthesia related deaths frequently occurred after anesthesia, especially within the last three hours of anesthetic effects. Joubert (2000) and Dyson et al. (1998) observed that the risk of anestheticrelated death in dogs was about $0.1 \%$ which was much higher than in humans. Cardio-respiratory complications are common hazards during anesthetic practices (Merry et al., 2017).

Premedicant drugs are usually being used before anesthetic induction to minimize the risks associated with general anesthesia (Brodbelt, 2006; Clarke et al., 2014). Atropine sulfate is the most used premedicant to check bradycardia, vagal effects, muscular spasms, salivary and gastrointestinal secretions (Ko et al., 2001; Liga and Edite, 2011). Xylazine hydrochloride (HCl) being a potential and widely applied alpha-2 agonist (Nesgash et al., 2016) elicits sedative and analgesic properties by inhibiting catecolamine and dopamine. Thus, it blocks nerve impulses to central nervous system resulting in relaxation of striated muscles. On contrary, according to White et al. (1980) Ketamine $\mathrm{HCl}$ is a dissociative agent which provokes profound analgesia, elevates heart rate and arterial pressure resulting in cardiovascular stimulation. The sole use of Ketamine may cause muscular hypertonicity, myoclonus and convulsions (Nesgash et al., 2016, Munif et al., 2020). For these reasons, Ketamine is often used in combination with other group of drugs e.g., Diazepam or Xylazine to avoid the unnecessary risks (Dzikiti et al., 2008; Ozkan et al., 2010). Thiopental sodium, a short acting barbiturate for animals (Lumb and Jones, 1984; Hall et al., 2000), is one the most chosen anesthetic drugs by the veterinary surgeons (Muhammad et al., 2009) for its effective hypnotic properties that causes depression of the central nervous system (Saini et al., 2017). It is used slowly and intravenously during anesthetic induction for various surgical approaches in dogs (McClune et al., 1992). Potliya et al. (2015) reported that every single anesthetic agent exerts typical effects on the functions of certain vital organs, and the clinical, hematological and biochemical properties of different body systems can be altered (Lobetti and Lambrechts, 2000; Hall et al., 2001; Joubert and Lobetti, 2002; Kabara et al., 2003; Luna et al., 2004; Anandmay et al., 2016).

Hence balanced anesthesia is necessary to reduce the unwanted sensory, motor, sympathetic and parasympathetic actions (Kaseem et al., 2019) as well as for smooth recovery from anesthesia. Therefore, this research work was focused on the investigation of some important hematobiochemical changes associated with XylazineKetamine and Xylazine-Thiopentone anesthesia in atropinized dogs.

\section{Materials and methods}

This research work was carried out from February to November 2018 in the Veterinary Teaching Hospital of Bangladesh Agricultural University, Mymensingh-2202 to find the effects of Xylazine-Ketamine and Xylazine-Thiopentone anesthesia on some hematological and biochemical indices in dogs premedicated with Atropine sulfate. This experimental methodology was approved by the Animal Welfare and Experiment Ethics Committee of Bangladesh Agricultural University (Approval No. AWEEC/BAU/2021-35).

\section{Experimental Animals}

With the consent of the animal owners, this research work included six (6) mature dogs of 18 to $25 \mathrm{~kg} \mathrm{BW}$, irrespective of sex and breed from the regular cases of various superficial wounds admitted to the Veterinary Teaching Hospital of Bangladesh Agricultural University. Before anesthetic induction, the dogs were kept off feed and water about 16 hours, and after proper anesthesia the wounds were surgically treated followed by supportive medicines. 


\section{Xylazine-Ketamine and Xylazine-Thiopentone anesthesia in dogs}

\section{Experimental Groups}

For this experiment, the dogs were divided into two groups: Group I and Group II, each consisting of three dogs. Before anesthetic induction, the dogs in both groups were premedicated intramuscularly with Atropine sulfate@ $0.05 \mathrm{mg} / \mathrm{kg}$ BW. In Group I (n=3), dogs were anesthetized with Xylazine-Ketamine combination, whereas Xylazine-Thiopentone combination were used to anesthetize the dogs in Group II (n=3). Xylazine HCl @ 1.1 mg/kg BW was used as intramuscular (IM) injection followed by proper premedication in both groups. After 10 minutes, Ketamine $\mathrm{HCl} @ 5.5 \mathrm{mg} / \mathrm{kg}$ BW as IM injection and Thiopentone sodium @ $20 \mathrm{mg} / \mathrm{kg} \mathrm{BW}$ as slow intravenous (IV) injection were used for induction of anesthesia in Group I and Group II respectively.

\section{Experimental Procedures}

Under general anesthesia, the dogs in both groups were passed through the management of superficial wounds, and their blood samples were collected for relevant hemato-biochemical analysis. For blood collection, the radial vein was raised manually by thumb pressure at the lateral aspect of the elbow joint, and $5 \mathrm{ml}$ of disposable plastic syringe with needle was used in each case. Five (5) samples, each consisting of $5 \mathrm{ml}$ blood were drawn from each experimental animal at different intervals e.g., prior to premedication (control), and then at 10, 20, 30 and 40 minutes after induction of anesthesia. Finally, one sample after complete recovery from anesthesia (360 minutes after induction) was obtained from each dog. Immediately after collection, the $5 \mathrm{ml}$ samples were divided into $3 \mathrm{ml}$ and $2 \mathrm{ml}$ in each case for transferring into the clot activator tubes and EDTA tubes respectively. For both groups, the blood sample containing tubes were marked and labeled carefully.

\section{Evaluation of Hematological Changes}

Blood samples transferred in the EDTA tubes were subjected to the hematological analysis for total Erythrocyte Count (TEC), Hemoglobin (Hb) and Packed cell volume (PCV). An automated hematology analyzer (Sysmex XS-2000i Automated Hematology Analyzer) was used to run the analysis on the blood samples.

\section{Assessment of Biochemical Changes}

Blood samples transferred into the clot activator tubes were allowed to stay in the tube rack at room temperature for 30 minutes. Then the samples were centrifuged at $3000 \mathrm{rpm}$ for 15 minutes. Finally, the separated serum samples were collected in eppendorf tubes using micro pipette and were subjected to the biochemical analysis for Total Serum Protein (TSP), Blood Urea Nitrogen (BUN), Creatinine, Sodium (Na), Potassium (K) and Chloride (Cl). The biochemical tests were performed by using Microlab 300 Semi-automated Biochemistry Analyzer and Medica EasyLyte PLUS $\mathrm{Na} / \mathrm{K} / \mathrm{Cl}$ Analyzer.

\section{Statistical Analysis}

The data obtained from this research work were calculated as 'mean \pm standard error' for all the cases in both groups. Paired t-tests were performed for data analysis using IBM SPSS Statistics (Version 20) to investigate the changes in same animals at certain hemato-biochemical levels during Xylazine-Ketamine and XylazineThiopentone anesthesia. $\mathrm{P}<0.05$ was considered as statistically significant for the tests.

\section{Results}

The effects of Xylazine-Ketamine (X-K) and Xylazine-Thiopentone (X-T) anesthesia on Total Erythrocyte Count (TEC), Hemoglobin ( $\mathrm{Hb}$ ) and Packed Cell Volume (PCV) of dogs in both groups are shown in Table 1. In case of TEC, significant decreases $(\mathrm{P}<0.05)$ from the control value $(6.65 \pm 0.06 \mathrm{million} / \mathrm{cumm})$ were found throughout the experimental period in Group I $(\mathrm{X}-\mathrm{K})$, whereas in Group II (X-T); the decreases in TEC from the control value $(6.88 \pm 0.14$ million/cumm) were found throughout the experiment including significant changes $(\mathrm{P}<0.05): 6.54 \pm 0.13,6.57 \pm 0.09$ and $6.56 \pm 0.06$ 


\section{Munif and others}

million/cumm at 10, 20 and 30 minutes after the anesthetic induction. However, TEC values were found near to the level of control values in both groups after complete recovery from anesthesia (360 minutes after induction). In case of $\mathrm{Hb}$ concentration, significant decreases $(\mathrm{P}<0.05)$ were observed throughout the experiment for both Group I (X-K) and Group II (X-T). Although the $\mathrm{Hb}$ values were found near to the control levels in both groups after complete recovery from anesthesia. In case of $\mathrm{PCV}$, the decreases from the control value $(50.23 \pm 0.90 \%)$ were found throughout the experiment in Group I $(\mathrm{X}-\mathrm{K})$ including significant changes $(\mathrm{P}<0.05)$ : $47.33 \pm 0.90,43.43 \pm 0.69$ and $45.77 \pm 0.47 \%$ at 20 , 30 and 40 minutes after induction, whereas in Group II (X-T); the decreases from the control value $(48 \pm 0.76 \%)$ were observed throughout the experiment including significant changes $(\mathrm{P}<0.05): \quad 46.37 \pm 0.81, \quad 45.03 \pm 0.79 \quad$ and $43.73 \pm 0.83 \%$ at 10,20 and 30 minutes. However, PCV values were found near to the control levels in both groups after complete recovery.

Table 1: Changes in Total Erythrocyte Count (TEC), Hemoglobin (Hb) and Packed Cell Volume (PCV) during Xylazine-Ketamine (X-K) and Xylazine-Thiopentone (X-T) anesthesia in dogs

\begin{tabular}{|c|c|c|c|c|c|c|c|}
\hline Blood indices & Groups & $\begin{array}{c}\text { Control } \\
(\text { Mean } \pm \mathrm{SE})\end{array}$ & $\begin{array}{c}10 \text { min. } \\
(\text { Mean } \pm \mathrm{SE})\end{array}$ & $\begin{array}{c}20 \text { min. } \\
(\text { Mean } \pm \mathrm{SE})\end{array}$ & $\begin{array}{c}30 \text { min. } \\
(\text { Mean } \pm \mathrm{SE})\end{array}$ & $\begin{array}{c}40 \text { min. } \\
(\text { Mean } \pm \text { SE })\end{array}$ & $\begin{array}{l}\text { After complete } \\
\text { recovery/360 min } \\
\quad(\text { Mean } \pm \mathrm{SE})\end{array}$ \\
\hline \multirow{2}{*}{$\begin{array}{c}\text { TEC } \\
\text { (million/cumm) }\end{array}$} & $\mathrm{I}(\mathrm{X}-\mathrm{K})$ & $6.65 \pm 0.06^{\mathrm{a}}$ & $6.36 \pm 0.04^{\mathrm{b}}$ & $6.29 \pm 0.04^{b}$ & $6.39 \pm 0.03^{b}$ & $6.52 \pm 0.07^{\mathrm{b}}$ & $6.65 \pm 0.06^{\mathrm{a}}$ \\
\hline & II (X-T) & $6.88 \pm 0.14^{\mathrm{a}}$ & $6.54 \pm 0.13^{b}$ & $6.57 \pm 0.09^{b}$ & $6.56 \pm 0.06^{b}$ & $6.68 \pm 0.02^{\mathrm{a}}$ & $6.84 \pm 0.08^{\mathrm{a}}$ \\
\hline \multirow{3}{*}{$\mathrm{Hb}(\mathrm{g} / \mathrm{dl})$} & $\mathrm{I}(\mathrm{X}-\mathrm{K})$ & $13.47 \pm 0.09^{a}$ & $12.63 \pm 0.12^{b}$ & $12.23 \pm 0.12^{b}$ & $11.93 \pm 0.09^{b}$ & $12.67 \pm 0.09^{b}$ & $13.50 \pm 0.06^{\mathrm{a}}$ \\
\hline & & & & & & & \\
\hline & II (X-T) & $14.03 \pm 0.15^{\mathrm{a}}$ & $13.53 \pm 0.12^{b}$ & $13.07 \pm 0.15^{b}$ & $12.70 \pm 0.06^{b}$ & $13.37 \pm 0.09^{b}$ & $13.93 \pm 0.30^{\mathrm{a}}$ \\
\hline \multirow{2}{*}{ PCV (\%) } & $\mathrm{I}(\mathrm{X}-\mathrm{K})$ & $50.23 \pm 0.90^{a}$ & $48.80 \pm 0.85^{\mathrm{a}}$ & $47.33 \pm 0.90^{b}$ & $43.43 \pm 0.69^{b}$ & $45.77 \pm 0.47^{b}$ & $50.87 \pm 0.86^{\mathrm{a}}$ \\
\hline & II (X-T) & $48.00 \pm 0.76^{\mathrm{a}}$ & $46.37 \pm 0.81^{b}$ & $45.03 \pm 0.79^{b}$ & $43.73 \pm 0.83^{b}$ & $46.67 \pm 1.13^{\mathrm{a}}$ & $47.67 \pm 0.94^{\mathrm{a}}$ \\
\hline
\end{tabular}

SE: Standard Error; $a, b$ : Values with different superscript letters in the same row differ significantly $(\mathrm{P}<0.05)$ 


\section{Xylazine-Ketamine and Xylazine-Thiopentone anesthesia in dogs}

Table 2: Changes in Sodium $(\mathrm{Na})$, Potassium $(\mathrm{K})$ and Chloride $(\mathrm{Cl})$ electrolytes during XylazineKetamine (X-K) and Xylazine-Thiopentone (X-T) anesthesia in dogs

\begin{tabular}{|c|c|c|c|c|c|c|c|}
\hline $\begin{array}{l}\text { Blood } \\
\text { indices }\end{array}$ & Groups & $\begin{array}{c}\text { Control } \\
(\text { Mean } \pm \text { SE })\end{array}$ & $\begin{array}{c}10 \text { min. } \\
(M e a n \pm S E)\end{array}$ & $\begin{array}{c}20 \text { min. } \\
(\mathrm{Mean} \pm \mathrm{SE})\end{array}$ & $\begin{array}{c}30 \text { min. } \\
(\text { Mean } \pm \text { SE) }\end{array}$ & $\begin{array}{c}40 \text { min. } \\
(\text { Mean } \pm \text { SE) }\end{array}$ & $\begin{array}{l}\text { After complete } \\
\text { recovery/360 min. } \\
(\text { Mean } \pm \text { SE) }\end{array}$ \\
\hline \multirow{2}{*}{$\begin{array}{l}\mathrm{Na} \\
(\mathrm{mmol} / \mathrm{L})\end{array}$} & $\mathrm{I}(\mathrm{X}-\mathrm{K})$ & $151.13 \pm 0.29^{\mathrm{a}}$ & $151.63 \pm 0.27^{b}$ & $149.27 \pm 2.38^{\mathrm{a}}$ & $149.83 \pm 1.43^{\mathrm{a}}$ & $151.13 \pm 0.33^{\mathrm{a}}$ & $151.47 \pm 0.49^{\mathrm{a}}$ \\
\hline & II (X-T) & $150.50 \pm 1.42^{\mathrm{a}}$ & $149.47 \pm 1.24^{\mathrm{b}}$ & $150.67 \pm 1.05^{\mathrm{a}}$ & $151.27 \pm 0.32^{\mathrm{a}}$ & $150.63 \pm 0.32^{\mathrm{a}}$ & $150.73 \pm 1.02^{\mathrm{a}}$ \\
\hline \multirow[t]{2}{*}{$\mathrm{K}(\mathrm{mmol} / \mathrm{L})$} & $\mathrm{I}(\mathrm{X}-\mathrm{K})$ & $4.51 \pm 0.04^{\mathrm{a}}$ & $4.52 \pm 0.21^{\mathrm{a}}$ & $4.28 \pm 0.07^{b}$ & $4.42 \pm 0.02^{\mathrm{a}}$ & $4.44 \pm 0.02^{\mathrm{a}}$ & $4.57 \pm 0.03^{\mathrm{a}}$ \\
\hline & II (X-T) & $4.61 \pm 0.15^{\mathrm{a}}$ & $4.44 \pm 0.14^{\mathrm{b}}$ & $4.36 \pm 0.16^{b}$ & $4.52 \pm 0.16^{\mathrm{b}}$ & $4.58 \pm 0.10^{\mathrm{a}}$ & $4.63 \pm 0.12^{\mathrm{a}}$ \\
\hline \multirow{2}{*}{$\begin{array}{l}\mathrm{Cl} \\
(\mathrm{mmol} / \mathrm{L})\end{array}$} & $\mathrm{I}(\mathrm{X}-\mathrm{K})$ & $115.57 \pm 0.27^{\mathrm{a}}$ & $117.20 \pm 0.21^{\mathrm{b}}$ & $117.83 \pm 0.23^{b}$ & $118.20 \pm 0.26^{\mathrm{b}}$ & $117.43 \pm 0.29^{b}$ & $115.80 \pm 0.49^{\mathrm{a}}$ \\
\hline & II (X-T) & $115.93 \pm 0.73^{\mathrm{a}}$ & $117.97 \pm 0.71^{\mathrm{b}}$ & $117.60 \pm 0.57^{\mathrm{a}}$ & $118.60 \pm 0.26^{b}$ & $117.67 \pm 0.27^{\mathrm{a}}$ & $115.93 \pm 0.38^{\mathrm{a}}$ \\
\hline
\end{tabular}

SE: Standard Error; a, b: Values with different superscript letters in the same row differ significantly $(\mathrm{P}<0.05)$

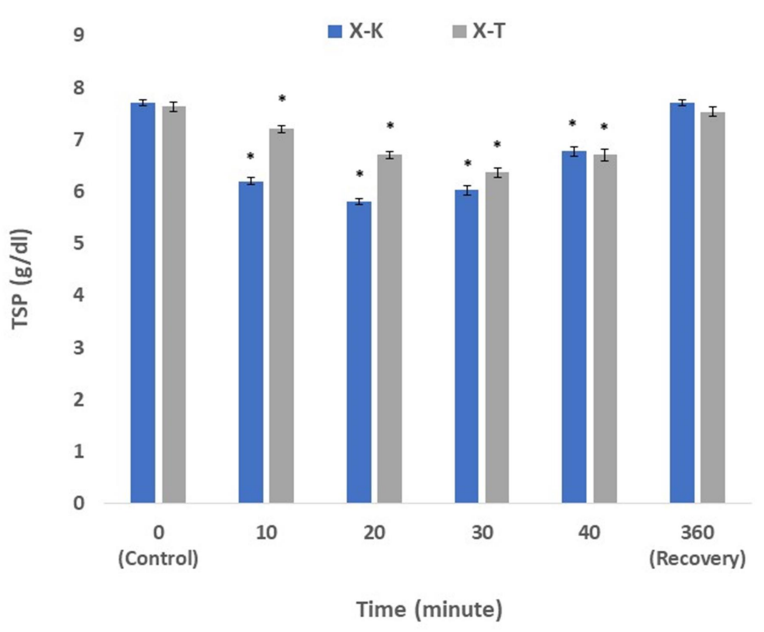

Figure 1: Changes in TSP $(\mathrm{g} / \mathrm{dl})$ during $\mathrm{X}-\mathrm{K}$ and $\mathrm{X}-\mathrm{T}$ anesthesia in $\operatorname{dogs}(* \mathrm{P}<0.05)$ 


\section{Munif and others}

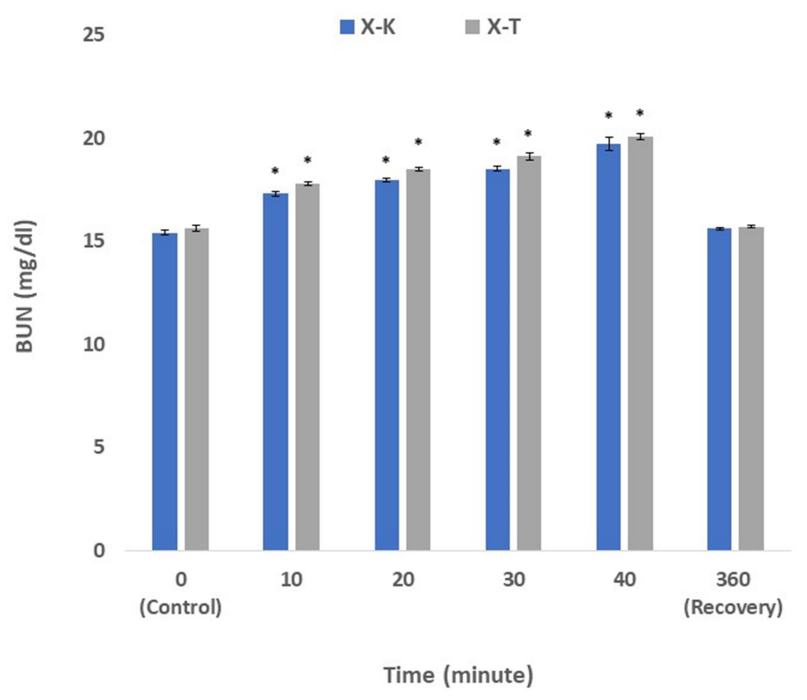

Figure 2: Changes in BUN (mg/dl) during $\mathrm{X}-\mathrm{K}$ and $\mathrm{X}-\mathrm{T}$ anesthesia in $\operatorname{dogs}\left({ }^{*} \mathrm{P}<0.05\right)$

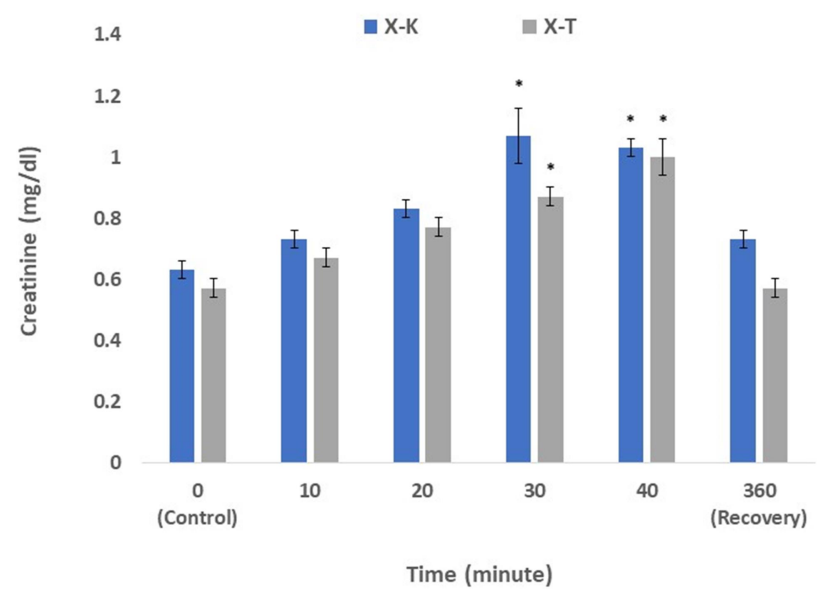

Figure 3: Changes in creatinine $(\mathrm{mg} / \mathrm{dl})$ during $\mathrm{X}-\mathrm{K}$ and $\mathrm{X}-\mathrm{T}$ anesthesia in dogs $\left({ }^{*} \mathrm{P}<0.05\right)$ 


\section{Xylazine-Ketamine and Xylazine-Thiopentone anesthesia in dogs}

The effects of X-K and X-T anesthesia on Total Serum Protein (TSP), Blood Urea Nitrogen (BUN) and creatinine of dogs in both groups are presented in Figure 1, Figure 2 and Figure 3 respectively. In case of TSP (Fig.1) for Group I $(\mathrm{X}-\mathrm{K})$, significant decreases $(\mathrm{P}<0.05)$ from the control value $(7.70 \pm 0.06 \mathrm{~g} / \mathrm{dl})$ were observed as $6.20 \pm 0.06,5.80 \pm 0.06,6.03 \pm 0.09$ and $6.77 \pm 0.09$ $\mathrm{g} / \mathrm{dl}$ at 10, 20, 30 and 40 minutes respectively after induction of anesthesia, although after complete recovery the value $(7.70 \pm 0.06 \mathrm{~g} / \mathrm{dl})$ was found near to the control level. Similarly, in Group II $(\mathrm{X}-\mathrm{T})$, significant decreases $(\mathrm{P}<0.05)$ from the control value $(7.63 \pm 0.06 \mathrm{~g} / \mathrm{dl})$ were observed as $7.20 \pm 0.06,6.70 \pm 0.06,6.37 \pm 0.09$ and $6.70 \pm 0.12 \mathrm{~g} / \mathrm{dl}$ at $10,20,30$ and 40 minutes respectively after induction of anesthesia, although after complete recovery the value $(7.53 \pm 0.09 \mathrm{~g} / \mathrm{dl})$ was found near to the control level.

In case of BUN (Fig. 2) for Group I (X-K), significant increases $(\mathrm{P}<0.05)$ from the control value $(15.40 \pm 0.12 \mathrm{mg} / \mathrm{dl})$ were observed as $17.30 \pm 0.12, \quad 17.97 \pm 0.09, \quad 18.50 \pm 0.12$ and $19.70 \pm 0.32 \mathrm{mg} / \mathrm{dl}$ at $10,20,30$ and 40 minutes respectively after induction of anesthesia, and after complete recovery the value $(15.60 \pm 0.06$ $\mathrm{mg} / \mathrm{dl}$ ) was found near to the control level. Likewise, in Group II (X-T), significant increases $(\mathrm{P}<0.05)$ from the control value $(15.63 \pm 0.12$ $\mathrm{mg} / \mathrm{dl}$ ) were observed as $17.77 \pm 0.09,18.47 \pm 0.09$, $19.13 \pm 0.17$ and $20.07 \pm 0.15 \mathrm{mg} / \mathrm{dl}$ at $10,20,30$ and 40 minutes respectively after induction of anesthesia, and after complete recovery the value $(15.70 \pm 0.06 \mathrm{mg} / \mathrm{dl})$ was found near to the control level.

In case of creatinine (Fig. 3) for Group I (X-K), the increases from the control value $(0.63 \pm 0.03$ $\mathrm{mg} / \mathrm{dl}$ ) were found as $0.73 \pm 0.03,0.83 \pm 0.03$, $1.07 \pm 0.09$ and $1.03 \pm 0.03 \mathrm{mg} / \mathrm{dl}$ at $10,20,30$ and 40 minutes respectively including significant alterations $(\mathrm{P}<0.05)$ at 30 and 40 minutes, but the value reversed as $0.73 \pm 0.03 \mathrm{mg} / \mathrm{dl}$ towards the control level after complete recovery from anesthesia. Comparably in Group II (X-T), the increases from the control value $(0.57 \pm 0.03$ $\mathrm{mg} / \mathrm{dl}$ ) were observed as $0.67 \pm 0.03,0.77 \pm 0.03$,
$0.87 \pm 0.09$ and $1.00 \pm 0.06 \mathrm{mg} / \mathrm{dl}$ at $10,20,30$ and 40 minutes respectively including significant alterations $(\mathrm{P}<0.05)$ at 30 and 40 minutes after induction of anesthesia, however the value reversed as $0.57 \pm 0.03 \mathrm{mg} / \mathrm{dl}$ towards the control level after complete recovery.

The effects of X-K and X-T anesthesia on Sodium $(\mathrm{Na})$, Potassium $(\mathrm{K})$ and Chloride $(\mathrm{Cl})$ electrolytes of dogs in both groups are shown in Table 2. In case of Na for both Group I (X-K) and Group II (X-T), the changes from the control values were observed throughout the experiment including significant alterations $(\mathrm{P}<0.05)$ only at 10 minutes, although the values turned towards the control levels after complete recovery from anesthesia. In case of $\mathrm{K}$ for both Group I (X-K) and Group II (X-T), the changes from the control values were observed throughout the experiment including significant alterations $(\mathrm{P}<0.05)$ only at 20 minutes in Group I and at 10, 20 and 30 minutes in Group II, although the values turned towards the control levels after complete recovery. In case of $\mathrm{Cl}$ for Group I (X-K), there were significant increases $(\mathrm{P}<0.05)$ from the control value throughout the experiment, whereas for Group II (X-T); the increases from the control value were observed throughout the experiment including significant changes $(\mathrm{P}<0.05)$ at 10 and 30 minutes. However, the values were found near to the control levels in both groups after complete recovery.

\section{Discussion}

In the research work, dogs were anesthetized with $\mathrm{X}-\mathrm{K}$ and $\mathrm{X}-\mathrm{T}$ combinations, which are parallel to the reports of several authors (Muhammad et al., 2009; Nesgash et al., 2016; Gebremedhin et al., 2018; Munif et al., 2020). Decrease in TEC levels were noted in the dogs during the experiment in both groups which are corresponding to other researches (Hausner et al., 1938; Kinge et al., 1985; Sankar et al., 2011) in various species. Likewise, decrease in $\mathrm{Hb}$ concentrations was found throughout the experiment in both groups which are in the agreements with the findings of several researchers (Kumar et al., 1979; Kumar et al., 1990; William et al., 1991). Again, decrease 


\section{Munif and others}

in PCV levels were observed in both groups which are correlated with many research findings (Hausner et al., 1938; Schalm, 1975; Kumar et al., 1979; Kumar et al., 1990). These decrease in TEC, $\mathrm{Hb}$ and PCV might be due to the pooling of circulating erythrocytes in the spleen (Nara et al., 1978) or other reservoirs secondary to decreased sympathetic stimulation (Amarpal et al., 1999; Das, 2013) or due to the inter-compartmental fluid shift in order to maintain normal cardiac output (Church et al., 1994; Das, 2013) or due to hemodilution in response to fluid therapy (Muir et al., 2007).

During this experiment, decrease of TSP levels were observed in dogs for both groups, which are collateral with the findings of other researchers (Bond and Parsons, 1970; Pavlica and Nemecek, 1970; William et al., 1991; Chitale et al., 1999). The decrease in TSP might be due to a fall in mean intra-capillary hydrostatic pressure during the anesthesia with the initial unaltered colloidal osmotic pressure. Therefore, fluid enters the circulation from the interstitial compartment, and the circulatory plasma proteins are diluted resulting in low TSP levels (Bond and Parsons, 1970).

This study furnished that creatinine increased in the dogs throughout the experiment in both groups. Similar findings in dogs were also reported by other authors (Tiwari et al., 1994; Lim et al., 2000; Manat and Kelawala, 2004; Nusory, 2011; Singh et al., 2014). In addition, increased levels of BUN were found in dogs of both groups. During anesthesia the increase in BUN has also been reported by others (Guzel et al., 2006; Sankar et al., 2011) in various species. The reasons for the increase in creatinine and BUN might be attributed to the temporary inhibitory effects of the anesthetic drugs on the renal cortical blood flow by constricting the blood vessels. Hence, the reduction in glomerular filtration rate ultimately results in increased levels of creatinine and BUN (Sankar et al., 2011).

There were mild and transient alterations in the values of $\mathrm{Na}, \mathrm{K}$ and $\mathrm{Cl}$ electrolytes in the dogs during the experiment in both groups, which are in agreements with the reports of other researchers (Soliman et al., 1965; Rao et al., 2002; Butola and Singh, 2003). Kumar and Sharma (1986) used X-T, and Kumar et al. (1979) used X-K anesthesia in dogs and found non-significant changes in the electrolyte levels. These all reveal that those anesthetic combinations do not considerably affect the electrolyte levels in dogs.

\section{Conclusion}

$\mathrm{X}-\mathrm{K}$ and $\mathrm{X}-\mathrm{T}$ anesthesia in premedicated dogs elicit some reasonable and certain hematological and biochemical changes except in some electrolyte levels. These hemato-biochemical changes should be of great concerns of the veterinarians and livestock practitioners while dealing with patients under general anesthesia as these could be the instant as well as long term challenges for the care and management of anesthetic patients.

\section{Competing Interest}

The authors declare that they have no competing interest.

\section{Acknowledgement}

The authors gratefully acknowledge the Ministry of Science and Technology of Bangladesh for funding and the Veterinary Teaching Hospital of Bangladesh Agricultural University for carrying out the research work smoothly.

\section{References}

1. Amarpal HP, Aithal HP, Singh GR. Preemptive effects of epidural ketamine for analgesia in dogs. Indian Veterinary Journal. 1999; 76(1): 300-303.

2. Anandmay AK, Dass LL, Sharma AK, Gupta MK. Haemato-biochemical changes following administration of propofol in combination with buprenorphine in atropinized dogs. Journal of Animal Research. 2016; 6(3): 531-536. 


\section{Xylazine-Ketamine and Xylazine-Thiopentone anesthesia in dogs}

3. Bond AG, Parsons RS. Haemodilution and plasma proteins during anesthesia. British Journal of Anesthesia. 1970; 42(1): 11131118 .

4. Brodbelt DC, Hammond R, Tuminaro D. Risk factors for anesthetic-related death in referred dogs. Veterinary Record. 2006; 158(1): 563-564.

5. Butola V, Singh B. Haemato-biochemical effects of midazolam and ketamine anesthesia in dogs. Indian Journal of Veterinary Surgery. 2003; 24(1): 44-45.

6. Chitale DK, Pratap AK, Singh GR, Gupta OP. Biochemical effects of ketamine with premedication of alpha-2 agonists and diazepam in goats. The Indian Veterinary Journal. 1999; 76(4): 304-305.

7. Church DB, Nicholson AI, Ilkiw JE, Emslie DR. Effect of non-adrenal illness anesthesia and surgery on plasma cortisol concentration in dogs. Research in Veterinary Science. 1994; 56(1): 129-131.

8. Cima DS, Sato K, Torrecilla JS, Iwata VT, Futema F. Comparative study between propofol and propofol-ketamine for induction of anesthesia in dogs. Brazilian Journal of Veterinary Research and Animal Science. 2016; 53(2): 146-152.

9. Clarke KW, Trim CM, Hall LW. Principles of sedation, analgesia, and premedication. In: Clarke KW, Trim CM, Hall LW (Eds.), Veterinary Anesthesia, 11th ed., W.B. Saunders, London, United Kingdom. 2014; pp. 75-112.

10. Das A. Evaluation of propofol and its combination with preanesthetics for total intravenous anesthesia in cat. M.V.Sc. Thesis, 2003. Central Agricultural University, Aizawl, Mizoram, India.

11. Dyson DH, Maxie MG, Schnurr D. Morbidity and mortality associated with anesthetic management in small animal veterinary practice in Ontario. Journal of the American Animal Hospital Association. 1998; 34: 325-335.

12. Dzikiti TB, Bester L, Cilliers I, Carstens A, Stegmann GF, Hubert J. Limb fracture during recovery from general anesthesia: an often tragic complication of equine anesthesia. Journal of the South African Veterinary Association.2008; 79(3): 145148.

13. Gebremedhin Y, Negash G, Fantay H. Clinical evaluation of anesthetic combinations of xylazine-ketamine, diazepam-ketamine and acepromazineketamine in dogs of local breed in Mekelle, Ethiopia. SOJ Veterinary Science. 2018; 4(2): 1-9.

14. Guzel O, Inal G, Cirakli ZT, Eraslan E, Aktas M. Effects of propofol and sevoflurane anesthesia on some physiological and biochemical parameters in rabbits. Medycyna Wet. 2006; 62(12): 1383-1386.

15. HallL W, Clarke KW, Trim CM. Anesthesia and analgesia. In: Hall LW, Clarke KW (Eds.), Veterinary Anesthesia, 10th ed., W.B. Saunders, London, United Kingdom. 2000; pp. 73-125.

16. HallL W, Clarke KW, Trim CM. Veterinary Anesthesia. Sounders, London, United Kingdom.2001; pp. 1-145.

17. Hausner E, Essex HE, Mann FC. Roentgenologic observations of the spleen of the dog under ether, sodium amytal, pentobarbital sodium and pentothal sodium anaesthesia. American Journal of Physiology.1938; 121(1): 387-391.

18. Joubert KE. Routine veterinary anesthetic management practice in South Africa. Journal of the South African Veterinary Association. 2000; 71: 166-172.

19. Joubert KE, Lobetti R. The cardiovascular and respiratory effects of medetomidine and thiopentone anesthesia in dogs breathing at an altitude of $1486 \mathrm{~m}$. Journal of the South African Veterinary Association. 2002; 73(3): 104-110.

20. Kabara S, Hirota K, Yoshioka H, Kudo T, Ishihara H, Matsuki A. Differential effects of thiopental on methacholine and serotonininduced bronchoconstriction in dogs. British Journal of Anesthesia. 2003; 91(3): 379-384.

21. Kassem MM, Nasr MY, Sadik KM, Belal SE. The effect of intravenous administration of propofol, thiopental, or propofol plus thiopental mixture in dogs undergoing experimentally liver insufficiency. 


\section{Munif and others}

Damanhour Journal of Veterinary Science. 2019; 2(2): 19-23.

22. Kinge AE, Pandey SK, Bhargava MK. Clinical and haematological observation on the use of diazepam GG and barbiturate combination in goats. Indian Journal of Veterinary Surgery. 1985; 6(1): 1-6.

23. Ko JC, Fox SM, Mandsager RE. Effects of preemptive atropine administration on incidence of medetomidine-induced bradycardia in dogs. Journal of the American Veterinary Medical Association. 2001; 218(1): 52-58.

24. Kumar A, Pandiya SC, Singh H. Canine anesthesia with a combination of ketamine and xylazine in experimental and clinical cases. Indian Journal of Animal Health. 1979; 18(1): 39-43.

25. Kumar A, Sharma AK. Thiopentone sodium with or without xylazine premedication in buffaloes. Indian Journal of Animal Science. 1986; 56(10): 1022-1029.

26. Kumar N, Kumar A, Singh B. Clinical and physiological effects of ketamine with and without diazepam or meperidine premedication in dogs. Indian Veterinary Journal. 1990; 67(1): 242-246.

27. Liga K, Edite B. The effects of some premedication and general anesthesia drugs on intraocular pressure and pupil diameter in dog's eyes. LLU preclinical institute, LLU Raksti. 2011; 26(1): 77-83.

28. Lim JH, Jang KH, Jang IH. Comparative effect of propofol or propofol and ketamine for the induction of anesthesia in dogs. Veterinary Record. 2000; 146(20): 571-574.

29. Lobetti R, Lambrechts N. Effects of general anesthesia and surgery on renal function in healthy dogs. American Journal of Veterinary Research. 2000; 61(2): 121-124.

30. Lumb WV, Jones EW. Pre-anestheticagents. In: Lumb WV, Jones EW (Eds.), Veterinary Anesthesia, $2^{\text {nd }}$ ed., Lea and Febiger, Philadelphia. 1984; pp. 165-197.

31. Luna SP, Cassu RN, Castro GB, TeixeiraNeto FJ, Silva-Junior JR, Lopes MD. Effects of four anesthetic protocols on the neurological and cardiorespiratory variables of puppies born by cesarean section. Veterinary Record. 2004; 154(13): 387-389.

32. Manat DKL, Kelawala NH. Studies on anesthetic evaluation of propofol, thiopental sodium as induction and maintenance agents in dogs. Indian Journal of Veterinary Surgery. 2004; 25(1): 54-56.

33. McClune S, McKay AC, Wright PM, Patterson CC, Clarke RS. Synergistic interaction between midazolam and propofol. British Journal of Anesthesia. 1992; 69: 240 245.

34. Merry AF, Mitchell SJ, Hardman JG. Hazards in anesthetic practice: general considerations, injury, and drugs. In: Hardman JG, Hopkins PM, Struys M (Eds.), Oxford Textbook of Anesthesia, Oxford University Press, United Kingdom. 2017.

35. Muhammad N, Zafar MA, Muhammad G, Masood MZ, Manzoor A, Sarfaraz I. Comparative anesthetic efficacy of propofol, thiopental sodium and combination of propofol with ketamine hydrochloride in dogs. Pakistan Veterinary Journal. 2009; 29(1): 11-15.

36. Muir WW, Hubbell JAE, Bednarski RM, Skarda RT. Introduction to anesthesia. In: Muir WW (Eds.), Handbook of Veterinary Anaesthesia, $4^{\text {th }}$ ed., Mosby Elsevier. 2007; pp. $15-50$.

37. Munif MR, Alam MM, Alam MR. Pulse oximetry and clinical changes during electrosurgery in dogs anesthetized with xylazine-thiopentone and xylazine-ketamine combinations. Research in Agriculture Livestock and Fisheries. 2020; 7(1): 97-105.

38. Nara RRS, Datt SC, Gupta RKP, Saxena SP. Effects of chloral hydrate anesthesia on certain haematological values in buffalo calves. Indian Veterinary Journal. 1978; 55(11): 884-889.

39. Nesgash A, Yaregal B, Kindu T, Hailu E. Evaluation of general anesthesia using xylazine-ketamine combination with and without diazepam for ovariohysterectomy in bitches. Journal of Veterinary Science and Technology. 2016; 7(1): 376-379.

40. Nusory D. Propofol and ketamine as a general anesthetic in dog. M.V.Sc. Thesis, 


\section{Xylazine-Ketamine and Xylazine-Thiopentone anesthesia in dogs}

2011. Assam Agricultural University, Guwahati-22, India.

41. Ozkan F, Çakır-Ozkan N, Eyibilen A, Yener T, Erkorkmaz U. Comparison of ketaminediazepam with ketamine-xylazine anesthetic combinations in sheep spontaneously breathing and undergoing maxillofacial surgery. Bosnian Journal of Basic Medical Sciences. 2010; 10(4): 297-302.

42. Pavlica J, Nemecek L. Medicomentous casting of cattle by thiopentobarbital with chlorpromazine premedication. Acta Veterinaria Brno. 1970; 39 (1): 435-455.

43. Potliya S, Kumar A, Singh S, Kumar S. Evaluation of efficacy and safety of glycopyrrolate-xylazine-propofol anesthesia in buffalo calves. Veterinary World. 2015; 8(3): 251-256.

44. Rao LN, Sharma AK, Swarup D, Kumar N. Investigation to determine the effects of detomidineand xylazine as preanaesthetics to thiopentone on the physiological and haemato-biochemical parameters in dogs. Indian Journal of Animal Science. 2002; 72(9): 779-780.

45. Saini R, Jadon NS, Kandpal M, Bodh D. Studies on the effects of thiopental sodium with and without dexmedetomidine in dogs. Indian Journal of Veterinary Surgery. 2017; 38(1): 44-46.

46. Sankar P, Jastin WB, Rao GD, Prathaban S, Suresh KR, Leela V. Cardiopulmonary and hematobiochemical alterations during ketamine or propofol anesthesia in acepromazine-xylazine premedicated horses. Indian Journal of Veterinary Surgery. 2011; 32(1): 23-26.

47. Schalm OW, Jain NC, Carral EJ. Veterinary Haematology, $3^{\text {rd }}$ ed., Lea and Febiger, Philadelphia. 1975; pp. 150-206.

48. Singh K, Kumar A, Kumar S, Potliya S, Singh S. Evaluation of triflupromazine propofol as an anesthethic combination in buffalo calves. Haryana Veterinarian. 2014; 53(2): 79-83.

49. Soliman MK, Amrousi SEL, Khamis MY. The influence of tranquilizers and barbiturate anesthesia on the blood picture and electrolytes of dogs. Veterinary Record. 1965; 77(43): 1256-1258.

50. Tiwari SK, Sharada R, Yadav SK. Clinical and haemato-biochemical response to ketamine with diazepam and xylazine premedication in dogs. Indian Veterinary Journal. 1994; 71(1): 943-945.

51. White P, Ham J, Way W, Trevor A. Pharmacology of ketamine isomers in surgical patients. Anesthesiology. 1980; 52(1): 231-245.

52. William BJ, David A, Balasubramanian NN, Mohammad MSDM. Procaine and lidocaine as adjuncts to thiopentone-sodium anesthesia in canine. Indian Journal of Veterinary Surgery. 1991; 12(1): 1-6. 